\title{
Peningkatan Kompetensi SDM Bidang F\&B Service pada Usaha Makanan dan Minuman Di Kawasan Puncak Kab. Bogor
}

\section{Increased Competence of HR in the Field of F \& B Service in Food and Beverage Enterprises in the Peak District. Bogor}

\author{
Vincent Sylvester Leewellyn ${ }^{1)}$, Nami Fitricia Pasaribu ${ }^{2)}$, Asep Syaiful Bahri ${ }^{3)}$ \\ 1) Program Studi Bisnis Perhotelan Universitas Agung Podomoro, Jakarta, Indonesia \\ 2) Program Studi Bisnis Perhotelan Universitas Agung Podomoro, Jakarta, Indonesia \\ 3) Program Studi Bisnis Perhotelan Universitas Agung Podomoro, Jakarta, Indonesia
}

19 April 2019

\begin{abstract}
According to BPS West Java Province data, the number of visits in 2016 for foreign tourists to Bogor Regency in 2016 reached 228,913 and 4,955,079 for domestic tourists. This data shows that the level of tourist visits to Bogor Regency continues to increase. The increase in tourist arrivals should be supported by facilities and infrastructure and business tourism services including tourism services in the field of food and beverages. Based on 2016 BPS data, the number of Restaurants / Restaurants by Regency / City in West Java Province, 2013-2016 was 162 businesses. This might be said to be still lacking in terms of numbers, in terms of service quality it can be said to be still lacking because if it is seen that the employees working in the sector are mostly graduates of junior high and high school. To improve the ability of HR (employees) who work in the food and beverage business services sector, activities are needed that aim to increase the capacity of human resources (employees) of food and beverage businesses in Bogor Regency. Community service regarding the Improvement of Excellent Services Capability in Food and Beverage Enterprises in the Bogor Regency Peak Area was attended by 30 participants who were employees in the business of food and beverage tourism services who were directly selected by the Bogor Regency Culture and Tourism Service. Based on the results of this community service activity, the following conclusions can be drawn: the provision of knowledge and technology on improving management capabilities Capability of Excellent Services in Food and Beverage Enterprises in the Peak District. Bogor was well received by the participants and achieved the goals planned previously. This is indicated by the ability of participants to be able to understand and direct practice regarding service excellent. In addition, there were participants who after this training were appointed as supervisors at the restaurant where the participants worked.
\end{abstract}

Keyword: Competence of HR in $F \&$ B Service, Food and Beverage Business

\begin{abstract}
ABSTRAK
Menurut data BPS Provinsi Jawa Barat, jumlah kunjungan pada tahun 2016 untuk wisatawan mancanegara ke Kabupaten Bogor pada tahun 2016 mencapai 228.913, dan 4.955.079 untuk wisatawan nusantara. Data ini menunjukkan bahwa tingkat kunjungan wisatawan ke Kabupaten Bogor terus meningkat. Peningkatan kunjungan wisatawan ini mestinya didukung oleh sarana dan prasarana dan usaha jasa wisata termasuk didalamnya adalah usaha jasa wisata dibidang makanan dan minuman. Berdasarkan data BPS 2016 jumlah Restoran/Rumah Makan Menurut Kabupaten/Kota di Provinsi Jawa Barat, 2013-2016 adalah sebesar 162 usaha. Hal ini mungkin bisa dikatakan masih kurang dari segi jumlahnya, dari segi kualitas layanan dapat dikatakan masih kurang karena jika dilihat bahwa karyawan yang bekerja di sektor tersebut sebagian besar merupakan lulusan SMP dan SMA. Untuk meningkatkan kemampuan para SDM (karyawan) yang bekerja di sektor jasa usaha makanan dan minuman tersebut, maka dibutuhkan kegiatan yang bertujuan untuk meningkatkan kapasitas SDM (karyawan) usaha makanan dan minuman di Kabupaten Bogor. Pengabdian kepada masyarakat mengenai Peningkatan Kemampuan Services Excellent pada Usaha Makanan dan Minuman Di Kawasan Puncak Kabupaten Bogor diikuti oleh 30 peserta yang merupakan karyawan di bidang usaha jasa wisata makanan dan minuman yang dipilih langsung oleh Dinas Kebudayaan dan Pariwisata Kabupaten Bogor. Berdasarkan hasil kegiatan Pengabdian masyarakat ini, maka dapat ditarik kesimpulan sebagai berikut: pemberian ilmu pengetahuan dan teknologi mengenai peningkatan kemampuan pengelolaan Peningkatan Kemampuan Services Excellent pada Usaha Makanan dan Minuman Di Kawasan Puncak Kab. Bogor diterima dengan baik oleh para peserta dan mencapai tujuan yang sudah direncanakan sebelumnya. Hal ini ditandai dengan kemampuan para
\end{abstract}


peserta untuk dapat memahami serta praktek langsung mengenai service excellent. Selain itu, terdapat peserta yang setelah pelatihan ini diangkat menjadi supervisor di restoran tempat peserta itu bekerja.

Kata Kunci: Kompetensi SDM Bidang F\&B Service, Usaha Makanan dan Minuman.

\section{PENDAHULUAN}

Industri pariwisata saat ini di Indonesia, menjadi perhatian Presiden dimana kedepannya diharapkan pariwisata akan menjadi penggerak utama perekonomian Indonesia. Target Presiden untuk mendatangkan wisatawan mancanegara untuk tahun 2019, sebesar 20 juta. Menurut Travelport, Pariwisata Indonesia pada tahun 2017 meningkat pertumbuhannya, dimana mencapai $25,68 \%$. Angka tersebut merupakan angka pertumbuhan tertinggi di dunia dalam bidang pariwisata. Menurut Menteri Pariwisata, Arief Yahya, (detikFinance, 2017), sejak tahun 2016, pendapatan devisa negara dari sektor pariwisata sudah melebihi dari pendapatan dari sektor migas. Diharapkan sektor pariwisata akan menjadi pendapatan utama devisa negara pada tahun 2019. Melihat target pada tahun 2019, tentunya perlu dipersiapkan dari berbagai aspek, salah satunya adalah Sumber Daya Manusia (SDM). Pengembangan SDM sangat dibutuhkan dalam pelayanan setiap kegiatan di bidang pariwisata kepada wisatawan (tourist). Akan tetapi hal ini seringkali mendapatkan perhatian yang rendah. Menurut Evans, Campbell, \& Stone House (2003), salah satu faktor yang berperan penting dalam industri pariwisata adalah SDM. Dimana SDM di sektor pariwisata merupakan manusia yang berada dalam organisasi khususnya berbasis jasa (servicebased organization), dan kembali lagi SDM sebagai faktor penentu dalam keberhasilan kinerja organisasi.

Dalam persiapan pengembangan SDM di Indonesia, sudah dipersiapkan dalam menghadapi ASEAN Mutual Recognition Arrangement (MRA) pada tahun 2015 kemarin. Dimana Menteri Pariwisata dan Ekonomi Kreatif Republik Indonesia membuat Peraturan Menteri Pariwisata dan Ekonomi Kreatif Republik Indonesia, Nomor PM.53/HM.001/MPEK/2013 tentang standar usaha hotel, dimana pada Bab 1 Pasal 2 Ayat (a), disebutkan bahwa menjamin kualitas produk pelayanan dan pengelolaan dalam rangka memenuhi kebutuhan dan kepuasan tamu. Menurut Pasal 3, dimana Ruang Lingkup dari Peraturan tersebut mencakup (a) usaha hotel; (b) aspek produk, pelayanan dan pengelolaan; (c) penilaian standar usaha hotel; (d) pembinaan dan pengawasan; serta (e) sanksi administratif. Proses pengelolaan yang dimaksud dalam peraturan tersebut mencakup proses mengidentifikasi dan pengembangan kompetensi.

Pemerintah telah menetapkan standar kompetensi untuk SDM di bidang pariwisata khususnya untuk hotel dan restoran dengan adanya Keputusan Menteri Tenaga Kerja dan Transmigrasi Republik Indonesia Nomor: KEP.239/MEN/X/2004, tentang Penetapan Standar Kompetensi Kerja Nasional Indonesia (SKKNI), hal tersebut menjadi acuan dalam proses standar kompetensi SDM khususnya untuk hotel dan restoran.

Dinas Kebudayaan dan Pariwisata Kabupaten Bogor merupakan unit teknis kepariwisataan di Kabupaten Bogor yang berfungsi untuk menjaga dan meningkatkan kualitas SDM di bidang pariwisata di Kabupaten Bogor. Menurut data BPS Provinsi Jawa Barat, jumlah kunjungan pada tahun 2016 untuk wisatawan mancanegara ke Kabupaten Bogor pada tahun 2016 mencapai 228.913, dan 4.955.079 untuk wisatawan nusantara. Data ini menunjukkan bahwa tingkat kunjungan wisatawan ke Kabupaten Bogor terus meningkat. Peningkatan kunjungan wisatawan ini mestinya didukung oleh sarana dan prasarana dan usaha jasa wisata termasuk didalamnya adalah usaha jasa wisata dibidang makanan dan minuman. Berdasarkan data BPS 2016 jumlah Restoran/Rumah Makan Menurut Kabupaten/Kota di Provinsi Jawa

Barat, 2013-2016 adalah sebesar 162 usaha. Hal ini mungkin bisa dikatakan masih kurang dari segi jumlahnya, dari segi kualitas layanan dapat dikatakan masih kurang karena jika dilihat bahwa karyawan yang bekerja di sektor tersebut sebagian besar merupakan lulusan SMP dan SMA. Untuk meningkatkan kemampuan para SDM (karyawan) yang bekerja di sektor jasa usaha makanan dan minuman tersebut, maka dibutuhkan kegiatan yang bertujuan untuk meningkatkan kapasitas SDM (karyawan) usaha makanan dan minuman di Kabupaten Bogor.

\section{LANDASAN TEORI}

Pada industri jasa, pelayanan merupakan faktor yang sangat penting. Dimana pelayanan adalah sebuah aktivitas atau proses interaksi antara karyawan dengan pelanggan atau tamu. Pada dasarnya setiap manusia membutuhkan pelayanan dan akan melayani satu sama lain dalam memenuhi kebutuhannya, dan hal ini 
dapat dikatakan bahwa pelayanan tidak dapat dipisahkan dalam kehidupan manusia (Sinambela, 2010).

Menurut Swasto (2003), terdapat dua Jenis pelatihan dimana dapat berupa pelatihan berbasis pengetahuan dan pelatihan berbasis keterampilan. Pelatihan berbasis pengetahuan merupakan pelatihan dari para peserta dengan tujuan memiliki wawasan yang luas serta memberikan pengetahuan baru yang sesuai dengan kebuthan dari karyawan tersebut pada bidang pekerjaannya. Sedangkan pelatihan berbasis ketrampilan merupakan pelatihan secara langsung berupa kegiatan praktek di lapangan. Pelatih dalam pelatihan tersebut mengajarkan peserta untuk dapat mempraktekkan secara langsung sesuai dengan bidangnya. Pelatihan berbasis keterampilan sangat sering digunakan dikarenakan penyerapan materi lebih cepat dan mudah dipahami.

Menurut Dubois (2004), kompetensi merupakan karakteristik dimana setiap individu mempunyai kemampuan yang digunakan secara konsisten dengan tujuan untuk mencapai kinerja yang diinginkan. Kompetensi ini termasuk pada pengetahuan, keterampilan, aspek citra diri, motif social, sifat, pola piker, dan cara berpikir, perasaan dan pelaksanaan. Kompetensi adalah suatu proses yang mengacu kepada keahlian dan keterampilan yang harus dilakukan dan perilaku yang harus diterapkan dalam mencapai kinerja yang diinginkan (Sanghi, 2007).

Menurut Spencer (2007), menyatakan ada beberapa karakteristik kompetensi, diantaranya seperti (a) Pengetahuan, (b) Keterampilan, dan (c) Perilaku. Pengetahuan (a) dari setiap karyawan dapat membantu perusahaan dalam meningkatkan efisiensi, dimana ketika karyawan memiliki pengetahuan yang cukup, maka dapat mengurangi waktu dan tenaga dalam menghadapi kesulitan karena tidak memiliki pengetahuan yang cukup dalam bekerja. Keterampilan (b), dengan memiliki karyawan yang terampil, maka dapat membantu perusahaan dalam menjalankan pekerjaan dengan baik dan efisien juga. Sebagai gambaran, untuk karyawan yang baru masuk tanpa memiliki keterampilan, maka karyawan tersebut tidak dapat dibebankan dengan maksimal untuk tugas dan tanggung jawab sesuai dengan posisinya. Perilaku (c), selain dari pengetahuan dan keterampilan yang dimiliki, karyawan juga harus memiliki perilaku yang baik. Dimana perilaku dapat menentukan untuk mendukung pencapaian tujuan perusahaan. Apabila memiliki pengetahuan dan keterampilan yang baik akan tetapi tidak memiliki perilaku yang kurang baik, maka hasil yang dikerjakan oleh karyawan tersebut tidak maksimal. Contoh faktor yang termasuk dalam perilaku, seperti tingkat kedisiplinan, tanggung jawab terhadap pekerjaan dan sebagainya.

Menurut Tjiptono (2007), kualitas pelayanan merupakan upaya pemenuhan kebutuhan dan keinginan konsumen dimana perbandingan antara harapan dari kosumen dengan penyampaian pelayanannya. Apabila penyampaian pelayanan lebih rendah dari apa yang diharapkan konsumen, maka konsumen akan kecewa dan tidak puas. Apabila penyampaian pelayanan lebih tinggi dari harapan konsumen, maka konsumen akan puas. Faktor - faktor yang mempengaruhi kualitas pelayanan antara lain, (a) Tangibles, (b) Reliability, (c) Responsiveness, (d) Assurance, (e) Empathy.

Tangibles (a), berupa bukti nyata atau yang dapat terlihat oleh mata, seperti fasilitas fisik, kebersihan dan kerapihan dari karyawan, peralatan yang digunakan dalam operasional. Reliability (b), dimana konsistensi kerja dan kemampuan untuk dapat dipercaya dalam memberikan pelayanan kepada pelanggan. Pelayanan yang diberikan, dilakukan dengan tepat sesuai dengan apa yang dijanjikan atau ditawarkan, seperti ketepatan waktu pelayanan, dan pelayanan yang adil bagi seluruh pelanggan. Responsiveness (c), berupa kemauan dan kesiapan dalam memberikan pelayanan kepada pelanggan sesuai dengan kebutuhan pelanggan. Assurance (d), memastikan bahwa pelayanan tersebut dapat dengan mudah didapatkan oleh pelanggan dan dapat berkomunikasi dengan baik kepada pelanggan. Emphaty (e), pelayanan yang diberikan kepada pelanggan dengan sikap dan perilaku yang sopan, menghargai serta perhatian terhadap kebutuhan dan kepentingan pelanggan. 


\section{METODE PENELITIAN}

Pengabdian kepada masyarakat mengenai Peningkatan Kemampuan Services Excellent pada Usaha Makanan dan Minuman Di Kawasan Puncak Kabupaten Bogor diikuti oleh 30 peserta yang merupakan karyawan di bidang usaha jasa wisata makanan dan minuman yang dipilih langsung oleh Dinas Kebudayaan dan Pariwisata Kabupaten Bogor. Terdapat beberapa metode pengabdian yang dilakukan yakni dengan melakukan ceramah (penyuluhan) yang menekankan kepada prinsip dasar pelayanan dan bagaimana meningkatkan pelayanan yang prima dengan tujuan memberikan kepuasan kepada tamu. Setelah melakukan caramah (penyuluhan), para peserta pelatihan akan berdiskusi secara kelompok untuk menyusun aktivitas jika terjadi ketidakpuasan pada tamu atau yang sering dikenal juga dengan cara customer handling. Setelah berdiskusi para peserta akan mempresentasikan hasil diskusinya dan akan dikomentari oleh peserta yang lainnya, sehingga nantinya akan mendapatkan solusi yang konstruksif yang telah disepakati oleh para peserta.

\section{HASIL DAN PEMBAHASAN}

Sebelum kegiatan pelatihan service excellent dilakukan para penyuluh melakukan pre test yang bertujuan untuk mengetahui rata-rata tingkat pemahaman peserta mengenai konsep dasar service excellent yang nantinya akan menjadi dasar bagi pelatih kegiatan untuk dapat meningkatkan kapasitas karyawan baik dari segi pengetahuan maupun keterampilan. Berdasarkan hasil pres test yang dilakukan rata-rata tingkat pengetahuan para peserta berada pada kategori point 6,5. Hal ini menandakan bahwa para karyawan sudah memiliki pengetahuan mendasar mengenai service excellent, namun demikan masih juga terdapat ketidaktahuan peserta mengenai teknis atau praktek langsung mengenai cara baik dalam melayani tamu serta melakukan tindakan responsive apabila ada tamu yang merasa tidak nyaman atau complain kepada restoran tersebut. Hal ini mesti disesuaikan dengan pendapat atau teori yang menyatakan bahwa para karyawan harus responsive dalam memenuhi kebutuhan pada tamu (pelanggan). Untuk memberikan pengetahuan yang dapat meningkatkan kemampuan karyawan dalam melakukan aktivitas pelayanan perima maka perlu disampaikan materi-materi yang berkaitan dengan service excellent. Dari materi yang disampaikan paara pelatih pun meminta para peserta untuk memberikan tanggapan mengenai materi palatihan yang diberikan. Adapun tanggapan peserta mengenai materi yang diberikan disajikan pada gambar berikut;

Gambar 1. Tanggapan Peserta Mengenai Pelatihan Yang Diberikan

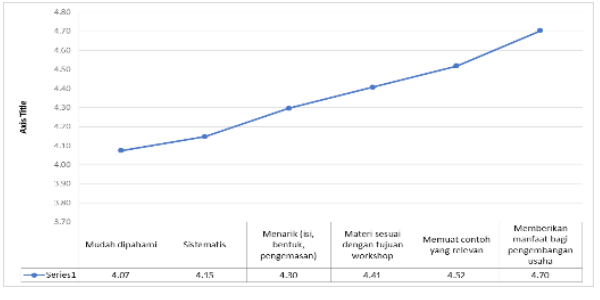

Berdasarkan gambar tersebut dapat dijelaskan bahawa rata-rata tanggapan responden mengenai materi yang diberikan berada pada kategori 4 yang artinya baik. Dan para peserta juga menganggap bahwa materi yang diberikan sangat memberikan manfaat bagi peserta dan dapat diaplikasikan ditempat para peserta bekerja.

Berdasarkan gambar tersebut terlihat bahwa proses kegiatan pelatihan dilakukan dengan cara santai namun tidak mengurangi kedisplinan para peserta, terlihat para pelatih memberikan pengetahuan mengenai berbagai macam bentuk perlengkapan yang ada di restoran serta teknik dalam melipat napkin. Gambar tersebut juga mencaritakan tentang praktek proses pelayanan dimana ada sebagaian peserta sebagai tamu dan sebagian pesertanya lagi sebagai pelayanan.

Hal yang perlu diperhatikan adalah penampilan serta kinerja dari para pelatih/penyuluh/narasumber. Kondisi ini perlu dilakukan agar terdapat umpan balik yang nantinya dapat dijadikan sebagai pijakan bagi para pelatih untuk bisa meningkatkan penampilan atau kinerja. Dari kuesioner yang telah disebarkan mengenai tanggapan peserta kepada para pelatih, menyatakan bahwa sebagian besar atau bahkan seluruh pelatih yang terlibat dalam kegiatan ini memiliki kompetensi yang baik dalam menyampaikan materi pelatihan, isi materi yang diiberikan, kemampuan menjawab pertanyaan dan memberikan contoh kasus yang relevan dan industry pariwisata, sampai kepada kemampuan pelatih untuk bisa mengajak peserta untuk bisa 
berdiskui dan bertannya mengenai materi yang telah diberikan. Kemampuan menggunaka peralatan-peralatan yang terdapat direstoran pun menjadi perhatian bagi peserta, para peserta mempunyai tanggapan bahwa para pelatih sangat professional dalam memperkenalkan perlengkapan restoran dan juga cara menggunakannya.

Dalam konteks teknis mengatasi masalah jika ada tamu yang complain, para pelatih pun mengajar para peserta menjadi tamu dan mengkomlain atas pelayanan yang diberikan oleh kawannya, hal ini menjadi sesuatu yang manarik dimana para pelayan tersebut mencoba untuk dapat mengatasi complain yang diberikan dan bagaimana cara mengatasinya. Hal ini mesti dilakukan mengingat para tamu yang datang ke restoran yang berada di Kabupaten Bogor adalah para wisatawan, baik wisatawan mancanegara maupun wisatawan nusantara yang harus dilayani secara maksimal dan memuaskan sehingga akan memberikan dampak psitif jika wisatwaan yang datang merasa puas. Untuk mengetahui tanggapan responden mengenai penampilan dan kinerja pelatih disajikan pada gambar berikut.

Setelah dilakukan pelatihan, diakhir sesi para peserta diberikan post test untuk melihat tingkat pengetahuan para peserta serta diberikan pelatihan. Berdasarkan hasil post test terdapat kenaikan yang significant atas tingkat pengetahuan dan pemahaman peserta mengenai service excellent. Adapaun nilai rata-rata post test peserta pelatihan adalah 9,8. Hal ini mendakan bahwa dengan kegiatan ini dapat meningkatkan pengetahuan dan pemahaman peserta mengenai service excellent bahkan dapat dibuktikan ketika para peserta tersebut melakukan praktek.

\section{SIMPULAN}

Berdasarkan hasil kegiatan Pengabdian masyarakat ini, maka dapat ditarik kesimpulan sebagai berikut: pemberian ilmu pengetahuan dan teknologi mengenai peningkatan kemampuan pengelolaan Peningkatan Kemampuan Services Excellent pada Usaha Makanan dan Minuman Di Kawasan Puncak Kab. Bogor diterima dengan baik oleh para peserta dan mencapai tujuan yang sudah direncanakan sebelumnya. Hal ini ditandai dengan kemampuan para peserta untuk dapat memahami serta praktek langsung mengenai service excellent. Selain itu, terdapat peserta yang setelah pelatihan ini diangkat menjadi supervisor di restoran tempat peserta itu bekerja..

\section{SARAN}

Adapun saran dalam kegiatan ini adalah perlu adanya kegiatan lebih lanjut yang berkaitan dengan manajemen usaha makanan dan minuman serta perlu adanya kegiatan studi banding yang mengajak para peserta pelatihan untuk melihat usaha makanan dan minuman di daerah tujuan wisata yang berkembang sehingga para peserta pelatihan dapat memahami kondisi diluar Kabupaten Bogor serta dapat menambah wawasan tentang pelayanan.

\section{DAFTAR PUSTAKA}

Dubois, D., Rothwell, J. W. (2004). Competency Based Human Resource Management. Davies-Black Publishing

Evans, Nigel, David Campbell \& George Stonehouse. (2003). Strategic Management for Travel and Tourism. Oxford: Butterworth-Heinemann

https://finance.detik.com/berita-ekonomi-bisnis/d3844660/pariwisata-jadi-andalanpenyumbang-devisa-us-20-miliar.

Pariwisata Jadi Andalan Penyumbang Devisa US\$ 20 Miliar. Di unduh pada tanggal 10 November 2018

Fandy Tjiptono, (2007), Strategi Pemasaran. Edisi ke dua, penerbit Andi, Yogyakarta

Keputusan Menteri Tenaga Kerja dan Transmigrasi Republik Indonesia Nomor: KEP.239/MEN/X/2004, tentang Penetapan Standar Kompetensi Kerja Nasional Indonesia (SKKNI),

Peraturan Menteri Pariwisata Dan Ekonomi Kreatif Republik Indonesia, Nomor PM.53/HM.001/MPEK/2013 Tentang Standar Usaha Hotel

Sanghi, (2007). S. SanghiThe Handbook of Competency Mapping: Understanding. Designing and Implementing Competency Models in Organizations (2nd ed.) Edition, 2, illustrated. Publisher, SAGE Publications, Incorporated, (2007). Original from, Pennsylvania State University.

Sinambela, L.P. (2010). Reformasi Pelayanan Publik;Teori,Kebijakan dan. Implementasi, cetakan kelima Jakarta: PT. Bumi Aksara. 
Spencer, N.Lyle and Spencer, M. Signe. (2007).

Competence at Work: Models for

Superrior Performance. John Wily \& Son,Inc. Mew York

Swasto. (2003). Pengembangan Sumber Daya

Manusia, Yogyakarta : STIE YKPN. 